\title{
A Longitudinal Investigation of the Moderating Effect of Social Support on Job Strain Developing Non-Specific Neck Pain in Office Workers
}

Deokhoon Jun

School of Health and Rehabilitation Sciences, University of Queensland, Brisbane, Australia; Department of Physical Therapy, College of Science, Kyungsung University, Busan, Korea

Purpose: This study examined the interactions between the job strain and social support in the workplace on the development of workrelated neck pain in office workers.

Methods: The participants included 62 office workers without neck pain over the last twelve months. A battery of measures evaluating the potential workplace risk factors in office settings were conducted at the baseline, and at the 12 month incidence of work-related neck pain was reported via monthly questionnaires. Survival analysis evaluated the interaction effect between job strain and social support on the development of work-related neck pain.

Results: The incidence of work-related neck pain was 1.91 (95\% Cl: $1.06-3.45)$ per 100 person months. The interaction effect between job strain and social support found that job strain may increase the risk of developing new work-related neck pain when lower social support existed in the workplace. On the other hand, the adverse effects of job strain on the development of neck pain were not significant when workers had higher social support from their colleagues and supervisors.

Conclusion: An investigation of the moderating effects of risk factors on neck pain might reveal the unexplained relationship between the risk factors for the development of neck pain in office workers. Therefore, the interest in prevention plans and treatments should involve a comprehensive understanding of the risk factors at workplace.

Keywords: Neck pain, Risk factors, Social support, Job strain, Moderating effect

서 론

목 통증은 재발성 질환으로 대부분의 근로자들이 일생에 한번쯤 겪 게 되는 통증이다.1,2 그 중 직업관련 목통증으로 인한 직장 내 근로자 의 장기부재, 그로 인한 감소된 생산력과 직업복귀를 위한 치료비용 등은 산업사회에 막대한 손실을 초래한다. 특히 다양한 직업들 중 사무직 근로자의 목통증 발생률과 유병률은 다른 직업군에 비해 높 은 수준으로 보고된다. ${ }^{4}$ 이런 높은 목통증 발생률과 관련된 사무직 의 특징은 장시간 컴퓨터 사용 및 좌식 근무 형태이다. 또한 신체의 먼 쪽 관절의 반복적인 움직임과 몸쪽 자세 유지근들의 지속적인 수 축 또한 사무직 근무의 특징이다. ${ }^{5}$ 이 비대칭적인 움직임은 컴퓨터 업 무 동안 척추 만곡 유지를 힘들게 하여 근골격계 질환을 유발할 수 있다. ${ }^{67}$
업무의 특징으로 인한 이런 물리적 원인을 넘어, 최근 역학 연구들 은 사회심리적 스트레스(psychological distress)가 사무직 근로자의 건 강상태에 악영향을 미치고 특히 허리통증이나 목통증과 같은 근골 격계 질환의 주요한 위험인자(risk factor)로 작용한다고 보고하였다. ${ }^{89}$ 다른 직종과 다르게 사무직 근로자들은 높은 강도의 심리적 근무 스 트레스를 경험하게 되고, 이런 심리학적 작업 긴장(job strain)은 물리 적 스트레스의 작용을 악화시켜 목통증 병리현상을 가속화 시키는 역할을 하게 된다. ${ }^{1011}$ 초기 연구들에서 이 현상은 직장에서 발생한 외 부 스트레스 요인이 한 개인의 정서적 반응을 일으켜 물리적, 심리적 긴장을 일으키는 통증 병리 현상의 연쇄화를 촉진시킨다고 설명하 였다.12,13 후속 연구들에서 제시된 모델은 초기모델의 이론을 바탕으 로 스트레스-통증 관계에서 사회적 지지(social support)와 같은 중재 역할을 하는 조절인자(moderating factor)를 소개하며 다차원적인 인
Received Aug 7, 2019 Revised Aug 21, 2019

Accepted Aug 26, 2019

Corresponding author Deokhoon Jun

E-mail hoon@ks.ac.kr
Copylight (C2019 The Korean Society of Physical Therapy

This is an Open Access article distribute under the terms of the Creative Commons Attribution Non-commercial License (Http:// creativecommons.org/license/by-nc/4.0.) which permits unrestricted non-commercial use, distribution, and reproduction in any medium, provided the original work is properly cited. 
과관계를 이해하려고 하였다. ${ }^{14,15}$

직장 내에서 심리적 부담이 주는 작용은 직업관련 목통증에 대한 연구들의 관심을 끌기에 충분했다. 특히 Karasek에 의해 제시된 "요구 통제 모델(control-demand model)은 근로자가 가지는 작업긴장도(job strain)를 해석하기에 적합했으며, 현재까지도 근로자, 일반인 대상자, 환자들을 대상으로 하는 건강 관련 연구에 폭넓게 이용되고 있다. ${ }^{16}$ 이 모델에서 개인의 스트레스 정도는 근로자가 수행해야 하는 업무 의 척도인 작업요구(job demand)와 근로자가 자신의 업무에 대한 의 사 결정권의 정도를 나타내는 작업제어(job control) 사이의 상호작용 에 의해 결정된다고 하였다. 예를 들어, 높은 수준의 작업요구를 가지 지만 자기업무에 대한 의사 결정권이 낮다면, 근로자의 작업긴장도 는 높은 수준으로 나타날 것이다. 최근 전향적 코호트 연구들에 따르 면, 이런 높은 작업긴장도를 가진 사무직 근로자들은 그렇지 않은 근 로자에 비해 높은 목통증 발생 비율을 나타낸다고 보고되었다.17-19

지금까지 전향적 연구를 통한 목 통증 위험인자에 대한 조사는 앞 서 언급한 초기 연구 모델들의 단차원적인 분석을 기반으로 한다. 예 를 들어, van den Heuvel et al. ${ }^{19}$ 의 연구에서 각 작업긴장도와 사회적 지지에 대한 직업관련 목통증 발생과의 일차원적인 선형적 관계(unidimentional linear relationship)가 각각 따로 보고되고 있고, 작업긴장 도와 사회적 지지의 상호작용이 직업관련 목통증 발생에 미치는 다 차원적인 인과관계는 분석되지 않았다. 현재까지 최근 모델에서 제 시한 목통증 발생 기전에서 다양한 조절인자들이 가지는 영향은 전 향적 연구에서 조사된 사례가 없다. 따라서, 직업관련 목 통증과 위험 인자의 인과 관계를 조사하고 그 관계 속에서 조절인자(사회적 지지) 의 역할을 알아보는 종적 연구의 필요성은 클 것이다. 그러므로, 이 연 구의 목적은 전향적 조사를 통해 직장 내에 존재하는 작업긴장도와 직업관련 목통증 발생률과의 인과관계를 파악하고 조절인자와의 상 호작용이 미치는 영향을 조사하는 것이다.

\section{연구 방법}

\section{1. 연구 설계 및 대상자 선정}

본 연구는 1년 전향적 연구(prospective design study) 방식을 택하여 경 산시 D 대학교에서 사무직 근로자를 대상으로 모집하였다. 대상자는 사내 공지, 건물 내 광고지 등을 통하여 모집 정보를 접하였다. 모든 대상자는 참여 동의서를 읽고 실험 내용을 충분히 인지한 후 참여의 사를 밝혔다. 본 실험은 연구 관리 위원회의 승인아래 시행되었다 (Human Research Ethics Committee in University of Queensland, Approval number-2014000308). 대상자 모집은 두 달간 진행되었고 총 81 명의 자발적 참여의사를 받았다. 그 중 62 명의 지원자만이 연구 대상 자자격조건을 만족하였다.

\section{2. 대상자 자격 조건}

연구 대상자 자격 조건은 다음과 같다. 1) 18세 이상 성인,2) 정규직 근 로자로 주간 30 시간 이상 근무, 3) 주간 20시간 이상의 컴퓨터 사용, 4) 지난 1년간 근골격계 질환을 가지지 않은 자. 목 통증은 성인기 이전 에 발병을 할 수 있으며, ${ }^{20}$ 재발성이기 때문에, 목 통증 병력은 현 대상 자의 목 통증 병리에 영향을 미친다. ${ }^{21}$ 따라서, 최근 1 년간 근골격계 질 환을 가진 지원자는 제외되었다.

\section{3. 대상자 위험인자 측정}

대상자의 개인적 요소(키, 나이, 몸무게 등)와 작업긴장도, 업무 지지, 개인적 심리 평가는 설문지를 통해 이루어 졌다. 대상자의 직장 내 사 무책상 환경을 측정하기 위하여 연구 시작점 이후 2 주 이내에 대상자 근무지를 방문을 하였다.

\section{1) 설문지 조사}

설문지는 대상자의 일반적 특성 묻는 간략한 질문들과 개인적 심리 와 신체활동 수준을 평가하는 두 가지 세부 설문지로 이루어졌다. 대 상자의 일반적 특성은 나이, 키, 몸무게, 직위, 흡연 유무, 음주량과 근 무조건(근무 시간, 컴퓨터 사용량, 근무 간 휴식 시간)을 포함하였다. 그리고 근로자가 가지는 개인적 심리(우울, 불안, 스트레스)는 한국형 으로 번역된 'depression, anxiety, and stress scale (DASS-21)'을 사용하였 다. 개인적 심리 측정을 위하여 한국형으로 번역된 이 평가지는 각 증 상 평가를 위해 7개의 항목으로 구성되어 있으며, 높은 수준의 신뢰 성과 타당도를 가진다.2근로자의 신체활동 수준을 평가하기 위하여 신뢰성과 타당도를 갖춘 'the international physical activity questionnaire (IPAQ-SF)를 사용하였다.23

\section{2) 직장 내 방문}

직장 내 방문을 통하여 대상자의 사무책상 환경을 평가하였다. 대상 자의 사무책상 환경 요소는 모니터의 높이(눈높이/눈높이 이하/눈높 이 이상), 마우스와 키보드의 위치(책상 끝에서부터 입력장치까지의 거리 $(\mathrm{cm})$, 책상의 높이 끝 부분 $(\mathrm{cm})$, 종이 문서의 위치(몸 쪽 가깝게/ 몸 쪽과 멀게), 의자의 높이(바른 앉은 자세에서 대상자의 팔꿉관절 높이가 책상 높이와 일치/팔꿉관절 높이가 책상 높이보다 낮음/팔꿉 관절 높이가 책상 높이보다 높음)를 포함하였다.

\section{4. 직업관련 목 통증 추적 조사}

대상자의 목 통증 발병 유무와 기간을 조사하기 위해 실험참여 날짜 를 기준으로 매달 30 일째 통증 유무를 조사하였다. 추적조사는 12 회 총 1년간 시행하였다. 목 통증의 유무는 Bone and Joint Decade 20002010 Task Force 가 제시한 목 통증 정의를 기준을 사용하여 판별하였 
다. ${ }^{24}$ 목 통증의 정의는 다음과 같다. 1) 일상생활을 방해할 정도의 통 증(잠, 독서, 컴퓨터 활동, 운전, 사회생활 등), 2) 결근이나 의학적 처치 (마사지, 재활, 통증약) 를 초래한 정도의 통증, 3 ) 통증의 범위는 견갑 골의 극상(spine of scapular) 부위와 목 아래 패임(supra sternal notch) 을 연결하는 부위부터 목 덜미선(superial nuchal line)까지로 정함. 직 업관련 목 통증과 외상성 목 통증을 구별하기 위하여 운동이나 불편 한 잠자리 등 특정한 신체활동 중 발생한 목 통증은 제외시켰다.

\section{5. 통계 분석}

직업관련 목 통증의 발병률과 생존분석(survival analysis)를 위해 Stata version 14 를 사용하였다. 목 통증 발병률은 카플란-마이어 생존지표 (Kaplan-Meier survival estimates)를 통해 분석하였다. ${ }^{25}$ 위험인자들과 목 통증 발병률의 인과관계를 분석하기 위하여 다변량 생존분석인 Multivariate Cox Proportional Hazard Analyses를 사용하여 목 통증 발 생 위험비(hazard Ratio)를 분석하였다. ${ }^{26}$ 다인자 분석(multivariable

Table 1. Distribution of risk factors included in the survival analysis

\begin{tabular}{|c|c|c|}
\hline Variables & $\begin{array}{c}\text { Index } \\
(n=58)\end{array}$ & $\mathrm{SD} / \%$ \\
\hline Age (years) & 37.17 & \pm 9.98 \\
\hline Female $(n / \%)^{*}$ & 24 & $41.38 \%$ \\
\hline $\operatorname{BMI}\left(\mathrm{kg} / \mathrm{m}^{2}\right)^{*}$ & 22.62 & \pm 3.50 \\
\hline Drinking per week (by 1 standard drinking) & 2.06 & \pm 0.81 \\
\hline Smoking $(n / \%)$ & 17 & $29.31 \%$ \\
\hline Hours of sitting during week days work and home (hr) & 49.53 & \pm 13.32 \\
\hline Hours of work per week (hr) & 41.79 & \pm 4.43 \\
\hline \multicolumn{3}{|l|}{ Hours of computer work per day (n/\%) } \\
\hline Less than 6 hours per day & 14 & $24.14 \%$ \\
\hline More than 6 hours per day & 44 & $75.86 \%$ \\
\hline Hours of work prior to break (hr) & 2.26 & 0.71 \\
\hline Physical activity (total MET)* & 2018.00 & \pm 1756.84 \\
\hline Job strain (score) & 16.59 & \pm 3.25 \\
\hline Social support (score) & 24.02 & 2.36 \\
\hline Depression symptom (score/21) & 3.19 & \pm 2.75 \\
\hline Anxiety symptom (score/21) & 2.64 & \pm 2.57 \\
\hline Stress symptom (score/21) & 5.18 & \pm 3.06 \\
\hline \multicolumn{3}{|l|}{ Computer screen levels (n/\%) } \\
\hline Eye level & 34 & $58.62 \%$ \\
\hline Lower than eye level & 18 & $31.03 \%$ \\
\hline Higher than eye level & 6 & $10.34 \%$ \\
\hline Distance of keyboard from the edge of the table $(\mathrm{cm})$ & 31.43 & \pm 10.19 \\
\hline Distance of mouse from the edge of the table $(\mathrm{cm})$ & 25.50 & \pm 9.31 \\
\hline \multicolumn{3}{|l|}{ Hard copy document positions (n/\%) } \\
\hline Adjacent to body & 41 & $70.69 \%$ \\
\hline Far from body & 17 & $29.31 \%$ \\
\hline Height of desk from floor (cm) & 73.37 & \pm 2.09 \\
\hline
\end{tabular}

BMl: body mass index, MET: metabolic equivalent minutes, ${ }^{*} p<0.05$. analysis)에서 필요한 인자선택중 과적합(overfitting) 오류를 최소화 하기 위해 least absolute shrinkage and selection operator (Lasso) 회귀분 석 모형을 적용하였다. ${ }^{27}$ 또한 회귀모형에 포함된 변수들의 수치 범위 를 통일화 시키기 위해 작업긴장도, 사회적 지지, 개인적 심리 변수들 에 대한 표준점수(Z-score) 변환을 시행하였다. 작업긴장도와 사회적 지지의 상호작용 분석을 위해 상관관계 변수(interaction term)를 회귀 모형에 포함시켰다. 최종 모형의 최적화 판단을 위해 Akaike's information criteria (AIC) 검증을 실시하였다. ${ }^{28}$ 생존분석의 유의수준은 $a$ $<0.05$ 로 설정하였다.

\section{연구 결과}

\section{1. 연구 대상자의 일반적인 특성}

62 명의 초대된 대상자중 4 명의 대상자는 실험을 완료하지 못하였다. 남은 58 명은 1 년간 추적조사를 모두 완료하였다. 대상자의 기본 정보 와 위험인자에 대한 정보는 Table 1에 기술하였다.

\section{2. 목 통증 발병률}

본 연구 대상자들의1년간 누적 발병률(cumulative incidence)은 $19.0 \%$ 로 총 11 명이 직업관련 목 통증을 호소하였다. 1 년 직업관련 목 통증 의 평균 발병률(incidence rate)은 $1.91(95 \% \mathrm{CI}: 1.06-3.45)$ per 100 person months로 나타났다(Figure 1). 발병률에서 남녀간 유의한 차이는 나 타나지 않았다 $(\mathrm{p}=0.73)$.

\section{3. 목통증 발병의 위험인자인 작업긴장도와 직업 지지의 상호작용}

다변량 생존 분석 시 대상자의 기본 정보인 나이, 성별, BMI는 인자 간 상관관계에 관련없이 분석에 포함되었다. Lasso 회귀분석을 통해 선택된 위험인자는 신체활동 수준(total MET score), 마우스 위치, 스

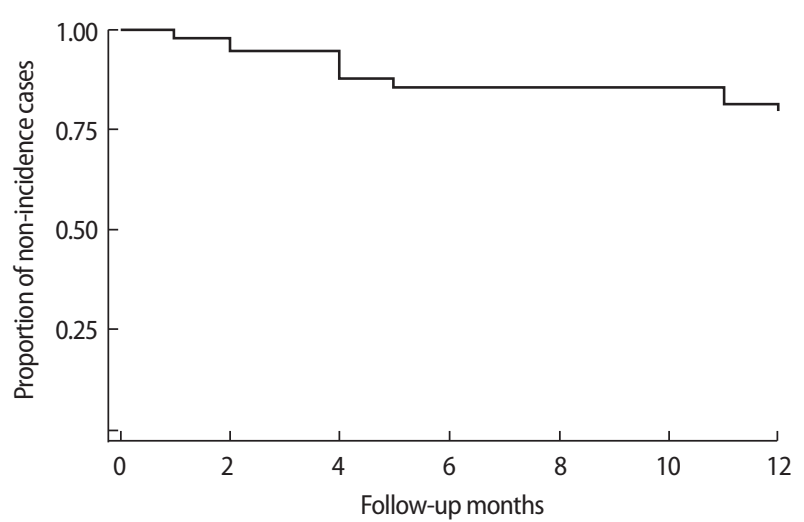

Figure 1. Kaplan-Meier survival curves for the incidence of work-related neck pain during the 12 months follow-up. The $Y$-axis describes the percent of participants each month of the follow-up period who did not report an episode of work-related neck pain. 
Table 2. Multivariate cox proportional hazard models indicating the calculated hazard ratio and significant association for risk factors and development of neck pain in office workers $(n=58)$

\begin{tabular}{lccc}
\hline Risk factors & Adjusted HR & $\mathrm{p}$ & $95 \% \mathrm{Cl}$ \\
\hline Age (decades) & 0.24 & 0.03 & $0.07-0.85$ \\
Female & 0.36 & 0.40 & $0.03-3.78$ \\
BMI (kg/m²) & 1.21 & 1.12 & $0.95-1.54$ \\
Stress symptom (score) & 3.20 & 0.03 & $1.16-8.86$ \\
Physical activity (total MET) & 1.00 & 0.16 & $1.00-1.00$ \\
Hours of work per week (hr) & 1.18 & 0.06 & $0.99-1.41$ \\
Distance of mouse from the edge of the table (cm) & 0.95 & 0.22 & $0.86-1.03$ \\
Job strain & 1.67 & 0.14 & $0.84-3.30$ \\
Social support & 1.82 & 0.13 & $0.83-3.99$ \\
Job strain X Social support (interaction term) & 0.34 & 0.03 & $0.13-0.91$
\end{tabular}

BMI: body mass index, MET: metabolic equivalent minutes, HR: hazard ratio, ${ }^{*} p<0.05$.

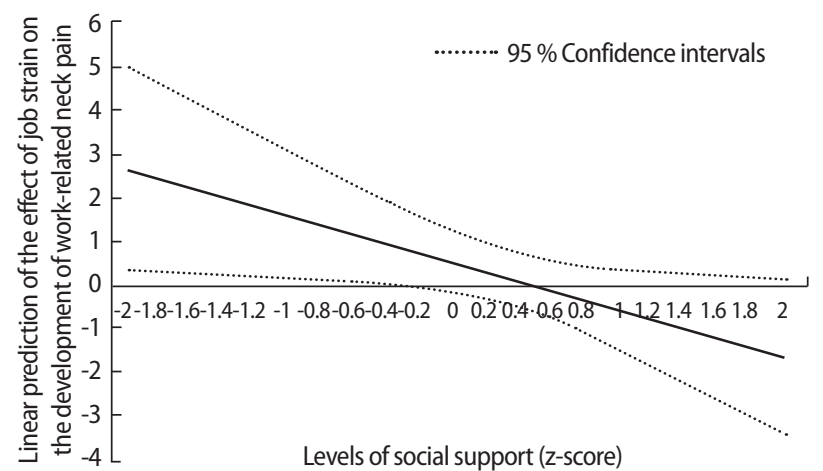

Figure 2. The marginal modifying effect of social support on the relationship between job strain and the development of work-related neck pain in office workers. The solid line indicates reduced adverse effects of job strain on the development of work-related neck pain as the levels of social support increase. The dotted-lines indicates both upper and lower 95\% confidence interval of the linear prediction of the effect of job strain on the development of work-related neck pain.

트레스 증상, 근무시간으로 정해졌다(Table 2). 대상자의 연령을 제외 하곤 성별, BMI 등의 기본 인자는 목 통증과의 유의한 인과관계를 나 타내지 않았다. 또한 직장 내 존재하는 사무실 책상의 환경과 신체활 동 또한 유의한 인과관계를 보이지 않았다. 하지만 개인이 가지는 스 트레스 증상은 목 통증 발생을 일으키는 위험 인자로 나타났다(hazard ratio: 1.37, 95\% CI: 1.03-1.84). 작업긴장도는 목통증 발생위험을 높 이는 인자로 나타났다. 그러나 이 인과관계는 근로자가 직장에서 얻 는 사회적 지지도의 평가점수가 평균보다 낮은 수준(Z-score<-0.3)으 로 유지될 경우에만 유의한 효과를 나타내었다 $(95 \%$ Confidence Interval 범위가 0 을 지나지 않는다)(Figure 2).

\section{고 찰}

본 연구결과는 개인이 가지는 기본 인자와 직장내의 존재하는 위험 인자들과 목 통증 발생률과의 인과관계를 조사함과 동시에 작업긴
장도와 사회적 지지의 상호작용이 목통증 발생률에 미치는 영향을 알아보았다. 본 연구결과는 단차원적인 위험인자들의 분석을 인자 들간의 상호관계를 조사하였고 이는 산업현장에서 직접 사용될 예 방법을 제시하기에 충분할 것이다.

직장 내의 작업긴장도와 근로자가 느끼는 심리적 스트레스는 목 통증 발생을 일으키는 위험인자로, 높아진 작업긴장도로 인한 심리 적 스트레스, 그리고 목통증으로 이어지는 인과관계를 설명한다. 이 전 연구에서 보고된 심리적 스트레스와 목통증 발병률과의 유의한 상관관계는 29 본 연구에서도 비교할 만한 수준을 나타났다. 유의하게 나타난 심리적 스트레스의 위험비 3.20은 Z-score로 변환된 스트레스 점수의 각 1 점 증가에 대한 3.2 배 증가된 목통증 발생률비를 설명하 며, Z-score의 1점은 표준편차의 크기와 동일하다. 따라서 사무직 근 로자의 특징적인 높은 심리적 스트레스는 목통증 예방 치료에 있어 꼭 평가되고 중재되어야할 인자로 생각된다.

직장 내에 존재하는 높은 작업긴장도는 이런 심리적 스트레스를 증가시키며 또한 목통증 발생의 위험도를 증가시키는 원인이 된다. ${ }^{30}$ 예를 들어 마감시간의 압박과 늘어난 업무량으로 대변되는 작업긴장 도는 반복적이고 증가된 키보드와 마우스 활동을 초래한다. ${ }^{31,32}$ 이런 평소와 다른 근무활동은 근육의 활동 변화와 컴퓨터 사용 및 근무 휴식의 다른 패턴을 유발할 수 있다.33,34 따라서 지속적인 작업긴장도 와 그로 인한 심리적 스트레스 같은 심리적 요인들은 근골격계 질환 을 일으키는 주요한 인자로 여겨지고 있다.35,36

이전 연구들에서 심리적 요인들의 부정적 영향을 감소시켜주는 역할을 하는 것은 직장 동료와 상사들로부터 받는 사회적 지지라고 보고된다. ${ }^{3738}$ 본 연구에서 작업긴장도가 가지는 목통증 발생률에 대 한 영향은 사회적 지지가 부족할 때만 유의하다는 결과를 확인 할 수 있었다(Figure 2). 지난 연구들에서 사회적 지지가 작업긴장도로 인해 발생하는 심리적 증상들을 감소시켜준다고 보고된다. ${ }^{38,39}$ Vanroelen et al. ${ }^{40}$ 등은 높은 수준의 사회적 지지는 근로자들을 격려하고 작업긴 
장도가 높다 하더라도 업무에 대한 근로자들의 동기를 더 촉진 시킬 수 있다고 하였다. 사회적 지지가 높은 근로자들은 작업긴장도로 인 해 받는 심리적 요인들의 악영향은 적을 것이고 이는 목통증 발병률 감소로 이어지는 예방적 조치로 생각된다.

본 연구에서 사무책상 환경 인자들과 목 통증 발생과의 유의한 인 과관계는 나타나지 않았다. 하지만 사무책상 환경은 목통증을 일으 키는 위험 인자 중에 하나이며 목통증 예방 중재에서 고려되어야 하 는 부분이다. 본 연구에서는 심리적 인자들의 영향이 다변량 생존분 석에서 더 강한 예측인자로 작용하였을 것이다.

후속 연구를 위해 본 연구가 가지는 몇가지 제한점이 있다. 목통증 발생에 기여하는 다양한 위험인자들을 평가하였지만, 대상자의 신체 적 능력, 근무자세, 근무지 밖에서 존재하는 다른 심리적 인자 등 다 른 잠재적 위험 인자들의 평가가 이루어 지지 못하였다. 그리고 상관 관계 분석을 위해 필요한 충분한 개체 수를 확보하지 못하였다. 또한 연구에서 사용된 설문지들은 심리적 인자들을 평가하기 위해 사용 되었지만 객관적 평가 자료보다는 주관적 평가자료이다. 후속 연구 에서는 다른 잠재적 인자를 포함하는 평가를 통해 목 통증의 위험성 과 그 인과관계를 밝히고, 또한 더 객관적인 평가도구들을 사용하여 연구결과의 질을 높일 수 있기를 기대한다.

본 연구 결과는 작업긴장도가 사무직 근로자의 직업관련 목 통증 발생에 미치는 영향과 사회적 지지와의 상호작용을 설명하였다. 직 장 내에서 필히 존재하는 두 인자는 수정 가능한 인자들이며, 임상 가들이나 연구가 혹은 산업재해 전문가들에게 직장 내 치료 중재에 있어 중요한 근거를 제시해 줄 것이다. 특히 본 연구 결과가 이미 알려 진 작업긴장도의 위험성을 충분한 수준의 사회적 지지로 완화시킬 수 있다는 것을 보았다. 그럼으로, 목 통증 예방 및 치료 계획은 수정 가능한 직장내 존재하는 위험인자들을 바탕으로 설계되어야 하며, 개인의 수준에서 중재할 수 있는 인자들 외에도 직장동료나 상사들 에게서 오는 외부적 인자들도 함께 고려되어야 할 것이다.

\section{ACKNOWLEDGEMENTS}

이 연구는 Office Ergonomic Research Committee지원아래 연구 되 었음을 알립니다.

\section{REFERENCES}

1. Cote P, Cassidy JD, Carroll LJ et al. The annual incidence and course of neck pain in the general population: a population-based cohort study. Pain. 2004;112(3):267-73.

2. Manchikanti L, Singh V, Datta S et al. Comprehensive review of epidemiology, scope, and impact of spinal pain. Pain physician. 2009;12(4):E35-
70.

3. Van Eerd D, Cote P, Kristman V et al. The course of work absenteeism involving neck pain: a cohort study of Ontario lost-time claimants. Spine. 2011;36(12):977-82.

4. Cote P, van der Velde G, Cassidy JD et al. The burden and determinants of neck pain in workers: results of the bone and joint decade 2000-2010 task force on neck pain and its associated disorders. J Manipulative Physiol Ther. 2009;32(2 Suppl):S70-86.

5. Punnett L, Bergqvist U. Visual display unit work and upper extremity musculoskeletal disorders: a review of epidemiological findings. Sweden, Arbetslivsinstitutet,1997.

6. Gerr F, Monteilh CP, Marcus M. Keyboard use and musculoskeletal outcomes among computer users. J Occup Rehabil. 2006;16(3):265-77.

7. Kotani K, Barrero LH, Lee DL et al. Effect of horizontal position of the computer keyboard on upper extremity posture and muscular load during computer work. Ergonomics. 2007;50(9):1419-32.

8. Janwantanakul P, Sitthipornvorakul E, Paksaichol A. Risk factors for the onset of nonspecific low back pain in office workers: a systematic review of prospective cohort studies J Manipulative Physiol Ther. 2012;35(7): 568-77.

9. Linton SJ. A review of psychological risk factors in back and neck pain. Spine. 2000;25(9):1148-56.

10. Griffiths KL, Mackey MG, Adamson BJ. Behavioral and psychophysiological responses to job demands and association with musculoskeletal symptoms in computer work. J Occup Rehabil. 2011;21(4):482-92.

11. Sjogaard G, Jensen BR. Low-level Static Exertions. The occupational Ergonomics Handbook. Boca Raton: CRC; 2000.

12. Levi L. Introduction: psychosocial stimuli, psychophysiological reactions, and disease. Stress and Distress in Response to Psychosocial Stimuli. Oxford: Pergamon Press; 1972.

13. Selye H. The stress of Life. New York: McGraw-Hill; 1956.

14. Feuerstein M. Workstyle: definition, empirical support, and implications for prevention, evaluation, and rehabilitation of occupational upper-extremity disorders. Beyond Biomechanics: Psychosocial Aspects of Musculoskeletal Disorders in Office Work. Oxford. Taylor and Francis. 1996.

15. Sauter SL, Swanson NG. An ecological model of musculoskeletal disorders in office work. Beyond biomechanics: Psychosocial aspects of musculoskeletal disorders in office work. Oxford. Taylor and Francis.; 1996.

16. Jason K, Steve J. Karasek's (1979) job demands-control model: a summary of current issues and recommendations for future research. New Developments in Theoretical and Conceptual Approaches to Job Stress. Bingley, Emerald Group Publishing Limited. 2010;8:237-68.

17. Eltayeb S, Staal JB, Hassan A et al. Work related risk factors for neck, shoulder and arms complaints: a cohort study among dutch computer office workers. J Occup Rehabil. 2009;19(4):315-22.

18. Ostergren PO, Hanson BS, Balogh I et al. Incidence of shoulder and neck pain in a working population: effect modification between mechanical and psychosocial exposures at work? Results from a one year follow up of the Malmo shoulder and neck study cohort. J Epidemiol Community Health. 2005;59(9):721-8.

19. van den Heuvel SG, van der Beek AJ, Blatter BM et al. Psychosocial work characteristics in relation to neck and upper limb symptoms. Pain. 2005;114(1-2):47-53.

20. Hogg-Johnson S, van der Velde G, Carroll LJ et al. The burden and de- 
terminants of neck pain in the general population: results of the bone and joint decade 2000-2010 task force on neck pain and its associated disorders. Spine. 2008;33(4 Suppl):S39-51.

21. Guzman J, Hurwitz EL, Carroll LJ et al. A new conceptual model of neck pain: linking onset, course, and care: the bone and joint decade 20002010 task force on neck pain and its associated disorders. Spine. 2008; 33(4 Suppl):S14-23.

22. Jun D, Johnston V, Kim JM et al. Cross-cultural adaptation and validation of the depression, anxiety and stress scale-21 (DASS-21) in the Korean working population. Work. 2018;59(1):93-102.

23. Oh JY, Yang YJ, Kang JH. Validity and reliablity of korean version of international physical activity questionnaire (IPAQ) short form. J Korean Acad Fam Med. 2007;28:532-41.

24. Guzman J, Haldeman S, Carroll LJ et al. Clinical practice implications of the bone and joint decade 2000-2010 task force on neck pain and its associated disorders: from concepts and findings to recommendations. Spine. 2008;33(4 Suppl):S199-213.

25. Kaplan EL, Meier P. Nonparametric estimation from incomplete observations. Journal of the American Statistical Association. 1958;53(282): $457-81$.

26. Shahidi B, Curran-Everett D, Maluf KS. Psychosocial, physical, and neurophysiological risk factors for chronic neck pain: a prospective inception cohort study. J Pain. 2015;16(12):1288-99.

27. Tibshirani R. Regression Shrinkage and Selection via the Lasso. J R Statist Soc. 1996;58(1):267-88.

28. Akaike H. A new look at the statistical model identification. IEEE Transactions on Automatic Control. 1974;19(6):716-23

29. Kraatz S, Lang J, Kraus T et al. The incremental effect of psychosocial workplace factors on the development of neck and shoulder disorders: a systematic review of longitudinal studies. International archives of occupational and environmental health. 2013;86(4):375-95.

30. Theorell T, Hammarstrom A, Aronsson G et al. A systematic review including meta-analysis of work environment and depressive symptoms.
BMC public health. 2015;15:738.

31. Birch L, Juul-Kristensen B, Jensen C et al. Acute response to precision, time pressure and mental demand during simulated computer work. Sand J Work Environ Health. 2000;26(4):299-305.

32. Eijckelhof BH, Bruno Garza JL, Huysmans MA et al. The effect of over commitment and reward on muscle activity, posture, and forces in the arm-wrist-hand region--a field study among computer workers. Sand J Work Environ Health.2013;39(4):379-89.

33. Bongers PM, Ijmker S, van den Heuvel S et al. Epidemiology of work related neck and upper limb problems: psychosocial and personal risk factors (part I) and effective interventions from a bio behavioural perspective (part II). J Occup Rehabil. 2006;16(3):279-302.

34. Potvin JR. Predicting maximum acceptable efforts for repetitive tasks: an equation based on duty cycle. Human factors. 2012;54(2):175-88.

35. Lundberg U, Johansson G. Stress and health risks in repetitive work and supervisory monitoring work. Engineering psychophysiology: Issues and applications. Erlbaum, New Jersey: 2000.

36. Waersted M, Eken T, Westgaard RH. Activity of single motor units in attention-demanding tasks: firing pattern in the human trapezius muscle. Eur Appl Physiol Occup Physiol. 1996;72(4):323-9.

37. Bonde JP. Psychosocial factors at work and risk of depression: a systematic review of the epidemiological evidence. Occup Environ Med. 2008; 65(7):438-45

38. Choi B, Ostergren PO, Canivet C et al. Synergistic interaction effect between job control and social support at work on general psychological distress. Int Arch Occup Environ Health. 2011;84(1):77-89.

39. Sanne B, Mykletun A, Dahl AA et al. Testing the Job demand-controlsupport model with anxiety and depression as outcomes: the hordaland health study. Occup Med (Lond). 2005;55(6):463-73.

40. Vanroelen C, Levecque K, Louckx F. Psychosocial working conditions and self-reported health in a representative sample of wage-earners: a test of the different hypotheses of the demand-control-support-model. Int Arch Occup Environ Health.2009;82(3):329-42. 